\title{
Law on Khamr under Qanun Jinayat in Aceh and Brunei Darussalam: A Comparative Study
}

\section{Muhammad Natsir, Cakra Arbas, Meta Suriyani}

Faculty of Law, Universitas Samudra, Indonesia. E-mail: munatsir_1966@unsam.ac.id Faculty of Law, Universitas Muhammadiyah Sumatera Utara, Indonesia. E-mail: cakraarbas@gmail.com Faculty of Law, Universitas Samudra, Indonesia. E-mail: metasuriyani@unsam.ac.id

\section{ARTICLE INFO}

\section{Keywords: \\ Criminal Legislation, Drinking Khamr, Qanun Jinayat and Shariah Court.}

How to cite: Natsir, M., Arbas, C., Suryani, M. Law on Khamr under Qanun Jinayat in Aceh and Brunei Darussalam: A Comparative Study, MEDIA HUKUM, +62 274387656 (Ext. 220)

Article History

Received: 19/09/2017

Reviewed: 09/05/2019 Revised:

Accepted: 29/06/2019

\begin{abstract}
Drinking khamr (liquor) is an offence under the Qanun Jinayat in Aceh and Brunei Darussalam. This paper aims at comparing the law relating to khamr in both jurisdictions. The study was made through content analysis using comparative approach. It is found that both in Aceh and Brunei Darussalam, drinking khamr is subjected to penalty in the form of whipping not exceeding 40 lashes. The sentence that was adopted from Islamic law (Sharia) to be imposed within a trial held by the shariah court. Beside similarity, there are some differences especially in relation to the applicability, enforcement and proceedings. The Qanun Jinayat of Aceh is applicable within its provincial territory, while the Qanun Jinayat of Brunei Darussalam is applicable within its national territory. In Aceh, the enforcement of the law on khamr involves the shariah judge. In Brunei Darussalam, besides involving the shariah judges, the enforcement of the law on khamr also involves the shariah prosecutor.
\end{abstract}

DOI: 10.18196/jmh.20190124

\section{Introduction}

Comparing the sentencing system in Aceh and Brunei Darussalam is interesting for some reasons. First, Sharia is a legal instrument both in Aceh and Brunei Darussalam whose implementation has a constitutional basis. ${ }^{1}$ Second, the implementation of Sharia in criminal matters (jinayat) is governed under a criminal legislation called Qanun

\footnotetext{
1 The implementation of Sharia in Aceh Province is a privilege granted by the central government of the Republic of Indonesia. Meanwhile, the Constitution of Brunei endorses the implementation of Sharia in Brunei Darussalam.
} 
Jinayat) and enforced through the shariah court (mahkamah syar'iyah). Third, although referring to the same legal source, ${ }^{2}$ however the application of criminal sanctions for drinking khamr (liquor) in both jurisdictions tends to be different.

As a matter of fact, Aceh and Brunei adopt two different legal systems. As a part of the Republic of Indonesia, the nature of the legal system prevailing in Aceh province is that of civil law system, the legal system which was developed and inherited from Roman legal system. The main characteristic of this legal system is codification. Codification (the formulation of legal rules into the code of law) is found in continental European countries such as Germany, the Netherlands, France, and Italy. Through colonization this legal system has spread out to Latin America and Asian countries, including Indonesia. ${ }^{3}$ On the other side, Brunei Darussalam adopts the common law system that relies on unwritten law. In this system, the judges are involved in the lawmaking process through the judicial judgment and therefore the law is developed from the court decision (precedent). ${ }^{4}$

It is interesting to be noted here that even though the legal system applied in Brunei Darussalam is that of the common law system, in fact this country also adopts civil law system especially in relation to the application of Sharia. There is a Qanun Jinayat (criminal legislation) in Brunei Darussalam like in Aceh. However, with regard to its applicability, Qanun Jinayat in Brunei Darussalam differs from its counterpart in Aceh. The applicability of Qanun Jinayat in Brunei Darussalam is based on the personality principle. The Qanun is applicable for all Brunei citizens including those living outside the country. However, with regard to the prohibition of drinking khamr, it is only applicable for Moslem residents. On the other side, the Qanun Jinayat of Aceh is applicable for Moslem residents who commit an offence within the territory of Aceh Province. It is not applicable for the same offense committed outside the jurisdiction and instead the Indonesian Penal Code is applicable. ${ }^{5}$ The article compares the law relating to khamr in Aceh Province and Brunei Darussalam.

\section{Method}

The type of research is normative legal research which studies secondary data in the form of legal materials. The data were collected through content analysis. Various sources relevant to this study have been studied especially Qanun Jinayat of Aceh and Qanun Jinayat of Brunei Darussalam. Comparative approach is employed in exploring the issue.

\footnotetext{
2 The law on khamr in Aceh and Brunei refers to the Shariah provisions that are derived from the primary sources (Quran \& Hadith) and the secondary sources (Ijma' and Qiyas).

3 Through the Dutch colonization, this legal system was brought to Indonesia. See http:/ / www.pengertianartidefinisi.com/pengertian-hukum-civi-law, accessed on 10 November 2016)

4 This legal system was adopted by the Commonwealth countries, North America, Canada, United States, and some Asian countries including Brunei Darussalam. In Brunei Darussalam, this legal system was introduced by the British colonial government and it is still applied today. See https:// www.google.com/pengertian +common+law, accessed on 10 November 2016.

5 Abbas, S. (2014). Pengantar Qanun Aceh Nomor 7 Tahun 2013 tentang Hukum Acara Jinayat, Aceh: Dinas Syari'at Islam, p. xx.
} 


\section{Analysis and Results}

\subsection{Regulation on Khamr in Islam}

The word khamr is derived from the verb khamara means it veiled or covered or concealed a thing, and wine is called khamr because it veils and shrouds the intellect of man. ${ }^{6}$ It refers to all kinds of intoxicating drink. ${ }^{7}$ Islam considers $k h a m r$ as one of the main factors that threaten the safety of religion, mind, life, property, and lineage. ${ }^{8}$ Therefore both its substance and its use is clearly forbidden both in the Qur' an and the Sunna of the Prophet PBUH. However, considering the historical fact that drinking khamr had for a long time been the part of the Arab communities' culture, the prohibition of drinking khamr was done gradually.

In the initial stage, the Quranic provision on khamr was quite lenient. One day, a group of companions including Umar and Muadh ibn Jabbal came to the Prophet for asking about khamr. In response to this question, surah al-Baqarah verse 219 was revealed. This verse says "they ask you concerning wine and gambling. Say: in them is great sin, and some benefit, for men; but the sin is greater than the benefit." This verse does not contain direct prohibition of drinking khamr rather an explanation that its sin is greater than its benefits. ${ }^{9}$

In the following, a stronger provision was revealed, namely Surah al Maidah verse 90 which stated, "O you who believe! Intoxicants and gambling, (dedication of) stones, and (divination) by arrows, are an abominations - of Satan's handwork: eschew such (abomination), that you may prosper." In this verse, there has been a demand to leave drinking khamr based on the ground that it constitutes satanic behavior. ${ }^{10}$

Another fact that had encouraged the revelation of Quranic provision on khamr was about a man who did prayer (shalat) while he was in drunken condition. He recited surah al-Kafirun and failed to complete it after several repetitions. In response to this, surah an-Nisa verse 43 was revealed. This verse states: "O you who believe! Approach not prayers with a mind befogged, until you can understand all that you say... " This verse indicated the increase in the prohibition of drinking khamr. Although prayer is obligatory for Moslems and it is even the pillar of religion, however someone is prohibited from performing prayer when he is drunk. ${ }^{11}$

The badness of khamr has been addressed by the Prophet in some descriptions. In a hadith narrated by at-Tabrani from Abdullah ibn Umar, the Prophet says, "khamar is the mother of crime and the greatest of major sins". In a hadith narrated by Ibn Majah from Abu Hurairah, the Prophet also described people who drink khamr are like worshipping idols, it means that they have lost their Islamic status. Due to the badness of khamr, not only those who drink khamr will be subjected to condemnation and

\footnotetext{
${ }^{6}$ Tajddin, M.A. "Khamr in Encyclopedia Topic", http://www.ismaili.net/heritage/node/10539, accessed on 11 May 2019.

7 Ammar, K. (2016). “The Quran's Prohibition of Khamr (Intoxicants): A Historical and Legal Analysis for the Shake of Contemporary Islamic Economic", Kyoto Bulletin of Islamic Area Studies, 9 (March), p. 97, https://www.asafas.kyoto-u.ac.jp/kias/pdf/kb9/04ea_02_ammar.pdf accessed on 11 May 2019.

8 http://infokito.wordpress.com/2008/01/17/khamar/, accessed on 24 November 2013.

${ }_{9}$ Ash-Shabuni, S. M. A. (2001). Shafwatut Tafasir, Jilid. I. Jakarta: Pustaka al-Kausar. p. 285.

10 Ibid. p. 97.

11 Ibid. p. 633.
} 
punishment, but also those who serve, sell, supply, create, cultivate and enjoy the benefit from the sale of khamr.12

The terms khamr has been extended to cover all kinds of intoxicating drink. The Prophet in a hadith narrated by Muslim and Ad-Daruquthny from Ibn Umar said, "Every intoxicant is khamr and every khamr is forbidden (haram)." In another hadith narrated by Ahmad and Ashhabussunan the Prophet said, "Every intoxicant is considered as khamr and every intoxicant is forbidden" The last reference relevant to this issue is a hadith containing the command of the Prophet to throw the bottle of khamr away. The Prophet said, "O people of Medina, Allah has determined the prohibition of khamr. So, whoever write this verse and still have it, do not drink and do not also sell it. But just throw it away on the streets of the city of Medina. ${ }^{13}$

Drinking khamr is subjected to hadd punishment. The law on khamr has been extended to any other intoxicating substances. The prohibition of khamr can be applied to other substances that are called under different names and for different use (other than to drink), ${ }^{14}$ as long as these substances have intoxicating effect like opium or other drugs ${ }^{15}$, the perpetrators will be subjected to hadd punishment.

Islam provides the limits and conditions for the infliction of hadd punishment against the perpetrators of drinking khamr. These include being sane, major, Muslims, not in the state of being forced, not in an emergency situation, and knowing that the object is khamr. For Muslims, khamr is not considered as beneficial property, therefore the action of destroying or spilling khamr belongs to others will not be subjected the person doing that action to compensate the owner, unless it belongs to the non-Muslim. ${ }^{16}$

Drinking khamr is subjected to hadd punishment in the form of whipping, however, the Prophet did not specify its amount. The companions set forth the punishment for the perpetrators either 40 or 80 lashes. In regard to this, Ali bin Abi Thalib said, "The Messenger of Allah punished the perpetrator with 40 lashes, and Abubakar was also with 40 lashes, while Umar imposed 80 lashes. All are the Sunnah of the Prophet and this is what I really like" ${ }^{17}$ Based on that hadith, the majority of scholar (jumhur 'ulama) set forth the punishment 40 lashes for drinking khamr. Other than this will be considered as $t a^{\prime} z i r$ punishment that is set by the ruler or the judge.

\subsection{Regulation on Khamr in Aceh, Indonesia.}

The enactment of the Law No. 11 Year 2006 on Aceh Government (Undang-undang Nomor 11 Tahun 2006 tentang Pemerintahan Aceh) laid down the legal basis for the implementation of Shariah (Syariat Islam) in Aceh. ${ }^{18}$ In this Act, the implementation of

12 http:/ /infokito.wordpress.com/2008/01/17/khamar/, accessed on 24 November 2013

13 Syaikh Faisal bin Abdul Aziz Alu Mubarak, Ringkasan Nailul Authar, Jilid 4, Jakarta: Pustaka Azzam, 2007, p. 546.

14 Syekh Salim bin Ied al-Hilali, Ensiklopedi Larangan menurut Al-Quran dan As-Sunnah, Jilid 3, Jakarta: Pusataka Imam Syafii, 1999, p. 250.

15 Sulaiman Rasyid, Figh Islam, Jakarta: Athahiriyyah, 1978, p. 415.

16 http://nicomunication.blogspot.com/2010/05/hukum-khamar-dalam-islam.html. Accessed on 20 May 2019.

17 See Mukhtasar, Muslim, 1047, Muslim III 1331 No.1707 (Abdul 'Azim bin Badawi Al-Khalafi, Jakarta: Pustaka As-Sunah, 2011, p. 845.

18 Term Shariah in this sense refers to the local term Syari'at Islam that covers three areas namely faith ('aqidah), law (syar'iyah), and moral (akhlaq). See Section 125 point (1) of the Law Number 11 of 2006 on Aceh Government. The second area, syar'iyah, covers various aspects including: worship ('ibadah), 
shariah is specifically governed in Section 125. Further government on its implementation is available in local legislation called qanun. ${ }^{19}$ Several qanun have been enacted in Aceh to deal with various legal issues including Qanun Jinayat which deals with criminal matters.

As stated in Section 127 point (1), both provincial and district government in Aceh is responsible for the implementation of Shariah in Aceh. While Section 128 point (2) determines that the enforcement of Shariah is under the authority of the Shariah court (mahkamah syar'iyah). Shariah court which is attached to the religious court (peradilan agama) is authorized to handle several cases including criminal cases.

The handling of criminal cases refers to Qanun Number 6 of 2014 on Islamic Criminal Law (Hukum Jinayat); and Qanun Number 7 of 2013 on Islamic Criminal Procedure (Hukum Acara Jinayat). The former (may be referred to as Qanun Jinayat) deals with the substantive matters, while the latter deals with procedural matters. The formulation of offences within the Qanun Jinayat in Aceh is in accordance the Islamic legal principles such as: "all useful things are allowed and all harmful things are banned", "don't bring harm to another as well as to yourself", and "every danger must be eliminated" ${ }^{20}$

There are two levels of Shariah court; court of the first instance and court of appeal. The court of the first instance is available in districts and called Mahkamah Syar'iyah Kabupaten/Kota, while the court of appeal is located in provincial level and called Mahkamah Syar'iyah Aceh. Shariah court judges are appointed by the president based on the recommendation from the Chief of the Supreme Court (Chief Justice). ${ }^{21}$

The decision of Aceh Shariah Court (Mahkamah Syar'iyah Aceh) can be brought to the Supreme Court for cassation examination. Likewise, conflict of jurisdiction between the Shariah and non-Shariah courts is under the authority of the Supreme Court to settle. ${ }^{22}$

Qanun Jinayat is also applicable to the non-Muslim residents who committed special offences which are not governed under the Indonesian Penal Code (KUHP) or other criminal legislations. The investigation of criminal offences as governed under Qanun Jinayat is conducted by the police investigator and public servant investigator. ${ }^{23}$

The law on khamr can be seen at Chapter IV of Qanun Jinayat (Qanun Number 6 of 2014). There are several offences relating to khamr as governed in Section 15 - 17. Section 15 (1) states that any person who deliberately drink khamr (liquor) is subjected to had punishment ('uqubat hudud) in the form of whipping not exceeding 40 lashes. As governed in Section 15 (2), the repetition of the mentioned offence will be subjected to hadd punishment in the form of whipping not exceeding 40 lashes and $\mathrm{ta}^{\prime} z i \mathrm{r}$ punishment ('uqubat $t a^{\prime} z i r$ ) in the form of either whipping not exceeding 40 lashes or a maximum fine of 400 grams of pure gold or a maximum 40 months of imprisonment.

family law (ahwal al-syakhshiyah), privat law (mu'ammalah), criminal law (jinayat), and judiciary (qadha). See Section 125 point (2) of the Law Number 11 of 2006 on Aceh Government.

19 See Section 125 point (3) of the Law Number 11 of 2006 on Aceh Government.

20 See Ahmad Ali, Menguak Teori Hukum dan Teori Peradilan, Jakarta: Brenada Media Group, 2012, p. 216.

21 Presidential Decree on Shariah Court 2003 (Keppres RI Nomr 11 Tahun 2003 tentang Mahkamah Syar'iyah dan Mahkamah Syar'iyah Propinsi di Propinsi Nanggroe Aceh Darussalam)

22 Pemerintah Provinsi Aceh http://id.wikipedia.org/wiki/Pemerintahan_Aceh, accessed on 24 August 2016.

23 Ibid. 
Section 16 (1) states that any person who intentionally produce, save/hoard, sell or bring in khamr is subjected to ta'zir punishment in the form either whipping not exceeding 60 lashes or a maximum fine of 600 grams of pure gold or a maximum 60 months of imprisonment. While Section 16 (2) states that any person who intentionally buy, carry/transport, or give khamr to somebody else is subjected to $t a^{\prime} z i r$ punishment in the form of either whipping not exceeding 20 lashes or a maximum fine of 200 grams of pure gold or a maximum 20 months of imprisonment.

Involving children in the commission of offenses as governed in Section 15 and 16 above constitutes an aggravating factor. According to Section 17 any person intentionally involving children in the commission of offenses intended in Section 15 and 16 is subjected to $t a^{\prime} z i r$ punishment in the form of either whipping not exceeding 80 lashes or a maximum fine of 800 grams of pure gold or a maximum 80 months of imprisonment. ${ }^{24}$

Ta'zir punishments employed as an alternative punishment are either whipping, imprisonment, or fine based on a ratio one lashes is equivalent to one month of imprisonment and ten grams of pure gold. Basically, the Qanun is not applicable to the non-Muslims residents unless they have voluntarily submitted themselves under its governance.

\footnotetext{
24 Since all those offenses are governed under the local criminal legislation (Qanun Jinyat), the enforcement of above-mentioned criminal provisions is under the authority of the Shariah court (Mahkamah Syar'iyah). See Komariah Emong Sapardjaja, “Qanun Aceh”, paper presented in Jakarta 07 March 2012.
} 


\subsection{Regulation on Khamr in Brunei Darussalam}

Brunei Darussalam, through the decree of Sultan Hasanal Bolkiyah, has formally applied the Shariah since $1^{\text {st }}$ May 2014. This policy was taken to protect the society from injustice resulting from the application of other law. A criminal legislation (Qanun Jinayat) has been enacted in to govern criminal behavior. This Qanun is applied based on personality principle. The Qanun Jinayat of Brunei Darussalam is applicable for all Brunei citizens regardless their religion whether Muslim or non-Muslim. It is also applicable to Brunei citizens living abroad. There is no judicial selection in criminal matters. All criminal cases are under the jurisdiction of the Shariah court. ${ }^{25}$

There are two judiciaries which concurrently operate in Brunei Darussalam; the judiciary which is operated based on the English law and the judiciary which is operated based on Shariah. In the past Shariah court in Brunei Darussalam dealt only with family matters, but now its jurisdiction has been expanded to cover various cases including criminal cases.

The implementation of the Islamic sentencing system in Brunei Darussalam is made gradually consisting of three stages. In the beginning only ta'zir punishment was applied, followed by the application of hadd punishment of any form except the death penalty in the second stage, and finally the hadd punishments was completely applied to all relevant cases. ${ }^{26}$

In Brunei Darussalam, liquor (or called 'arak') refers to all kinds of substance which bring about intoxicating effect. Drinking liquor is subjected to hadd punishment regardless it causes the person get drunk or not. Those committing the offence in the first attempt will be punished with whipping 40 lashes. Committing the same offence in the second attempt will be subjected to whipping not exceeding 80 lashes and in the third attempt will be subjected to whipping not exceeding 80 lashes complemented with a maximum 2 years of imprisonment. The last-mentioned punishment will be imposed for the further repetition.

The conviction requires several types of evidence. The evidence required to prove the offence and therefore to justify the imposition of hadd punishment is the offender's confession or testimony of two witnesses which is followed by the judge's belief after considering the testimony of witnesses. ${ }^{27}$

It is stated in Section 104 point (4) of the Qanun Jinayat of Brunei that every Muslim who manufactures, sells, advertises, serves, offers, gives, displays, owns, stores, buys liquor is considered to have committed an offence which is subjected to a maximum of $\$ 8,000$ of fine or a maximum 2 years of imprisonment or both.

The law on khamr in Brunei is also applicable for the non-Muslim citizens. It is stated in Section 104 point (5) that any non-Muslims who drinks liquor or intoxicant in public space is considered to have committed an offence which is subjected to a maximum $\$$ 8,000 of fine or a maximum 2 years of imprisonment, or both. While point (6) states that the non-Muslim who sells, advertises, serves, or shows liquor to Muslim is punishable with a maximum $\$ 8,000$ of fine or a maximum 2 years of imprisonment, or both.

\footnotetext{
25 Warta Kerajaan Negara Brunei Darussalam October 2013 Article 3.

26 http://m.bisnis./quick-news/read/20141001/78/261633/studi-qanun-jinayat-brunei-darussalam, accessed on 27 August 2016.

27 Warta Kerajaan Negara Brunei Darussalam October 2013 Article 104.
} 
An action to cause or influence another person doing an offence relating to liquor is also subjected to punishment. As stated in Section 105 (1), every Muslim who causes other person to drink, use, or produce khamr is considered to have committed an offence and should be punished with a maximum $\$ 4,000$ of fine or a maximum one years of imprisonment, or both. While point (2) states that the non-Muslims who encourages Muslim to make any offence relating to liquor is considered to have committed an offence which is subjected to a maximum $\$ 4,000$ of fine or a maximum one year of imprisonment, or both.

The issue of complicity is governed in Section 106. As stated in point (1), any person who participates in making the offence stipulated in Section 104 (1) is considered to have committed an offence which is subjected to a maximum $\$ 8,000$ of fine or a maximum 2 years of imprisonment or both. While participating in making the offence as governed in point (3), (4), (5) or (6) is punishable with a maximum $\$ 4,000$ of fine or a maximum one year of imprisonment, or both.

The form of had punishment for drinking khamr in Brunei Darussalam is whipping not exceeding 40 lashes. The conviction of hadd punishment requires the presence of evidence in the form of confession, testimony of two witnesses which is followed by the judge's belief after considering the witness testimony. When these requirements are not fulfilled, hadd punishment cannot be inflicted to the perpetrator. Instead, $t a^{\prime} z i r$ punishment will be imposed to the perpetrator, including the non-Muslim perpetrator.

\subsection{Comparison between Qanun Jinayat in Aceh and Brunei Darussalam}

\subsubsection{Similarities}

Islamic law (Sharia) is universal in nature. It is applicable to all Muslims regardless their nationality and citizenship. All Muslims wherever they are, are bound by the Islamic law including those living in Aceh and Brunei Darussalam.

Before formally applied in Aceh, Islamic law has actually been recognized by or even internalized within the Acehnese society. As a matter of fact, the customary law of Aceh was much influenced by the Islamic law. It can be said that the customary law was developed based on the religious-magical principle. Similarly, Islamic law has also been recognized within the Brunei society because since gaining its independence, Islamic law has been adopted as the basis of the state. These factors have made the introduction of Islamic criminal legislation (Qanun Jinayat) both in Aceh and Brunei received good acceptance from their society.

The development of Qanun Jinayat both in Aceh and Brunei Darussalam referred to the same sources, namely the Qur'an and the Hadith. The two Qanuns adopted the terms and concepts recognized under the Islamic jurisprudence. Therefore, drinking khamr (liquor) has been made an offence since this conduct is prohibited (haram) according to Islamic law and punishable accordingly. Under the Islamic jurisprudence, this prohibited conduct is punishable with hadd punishment therefore it falls under the category of hudud offences (jarimah hudud). Under Qanun Jinayat both in Aceh and Brunei, drinking khamr is also considered as jarimah hudud and punishable with hadd penalty in the form of whipping (40 lashes).

Qanun Jinayat both in Aceh and in Brunei are also recognizes $t a^{\prime} z i r$ punishment as the alternative to the hadd punishment. The forms of $t a^{\prime} z i r$ punishment are subjected to the discretion of the ruler of both jurisdictions based on the Islamic personality principle. 


\subsubsection{Difference}

Although referring to the same sources in formulating offences relating to khamr in each Qanun, some differences are found, especially with regard to the issue of applicability, sentencing system and enforcement.

As part of the Indonesian territory, the implementation of Islamic law (Sharia) in Aceh should be in accordance with national legal system and should be within the framework of the unitary state of the Republic of Indonesia. By virtue of the Law Number 11 of 2006 on Aceh Government, Aceh enjoys the privilege to apply Islamic law (Shariah) including criminal matters within its provincial territory. For this purpose, a local criminal legislation known as Qanun Jinayat has been enacted.

The enforcement of the criminal provisions laid down in the Qanun is done in the Shariah court (mahkamah syar'iyah) which is carried out by the shariah judges. Terms shariah judges refers to judges who have special competency on shariah ${ }^{28}$ and are appointed to deal with criminal cases under the jurisdiction of the shariah court.

The shariah court does not only receive, hear and adjudicate criminal cases filed by public prosecutor, but it also deals with criminal cases submitted by the criminal offenders themselves. Public prosecutors receive criminal cases from investigators. Besides delivering criminal cases based on their own investigatory processes, the investigators may also process criminal cases delivered by an agency called wilayatul hisbah. ${ }^{29}$

There are some characteristics of the law on khamr in Aceh. With regard to drinking khamr, the alternative sentences applicable for this offence are either whipping or fine in the form of pure gold. Its applicability is based on the Islamic personality principle and not based on a pure territoriality principle. Basically, the law on khamr is applied only to the Muslim residents however there is opportunity for the non-Muslim residents to submit themselves to this law. It means that the non-Muslim perpetrators can be brought to the shariah court and be prosecuted based on Qanun Jinayat. ${ }^{30}$

As already discussed, Brunei Darussalam formally applied the Islamic criminal law in 2014. The substantive law in criminal matters refers to an Act known as Qanun Jinayat. The enforcement is this substantive law is carried out in the Shariah court involving shariah judges and shariah prosecutors.

Qanun Jinayat of Brunei Darussalam binds both Muslim and the non-Muslim citizens. The applicability of this Qanun is based on personality principle which means the Qanun remains applicable to the Brunei citizens living abroad. With regard to khamar, the action of drinking khamr by the non-Muslim citizen will not bear criminal liability unless that action is conducted in public spaces. Drinking khamr in the public space by the non-Muslim citizen is punishable with either fine or imprisonment, or both. ${ }^{31}$

Differences between the Qanun Jinayat of Brunei Darussalam and the Qanun Jinayat of Aceh are found in several issues. In Brunei, drinking khamr in the first attempt is subjected to whipping not exceeding 40 lashes. This punishment will be aggravated to

\footnotetext{
28 So far, only the judges that have been equipped with the shariah perspective, while other agencies such as police investigators and public prosecutors have not.

29 Wilayatul Hisbah refers to a government agency which is responsible to the enforcement of public order.

30 Syahrizal Abbas, 2014: xix.

31 Warta Kerajaan Negara Brunei Darussalam October 2013 Chapter II Section 104 (5)
} 
80 lashes for the second attempt, while the third attempt will be subjected to 80 lashes and a maximum 2 years of imprisonment. In Aceh, drinking khamr in the first attempt is also punishable with whipping not exceeding 40 lashes. However, Aceh applies different punishment for the commission of that offence in the second attempt. In such a case, $t a^{\prime} z i r$ punishment is employed. Drinking khamr in the second attempt is subjected to whipping not exceeding 40 lashes, or a maximum fine of 400 grams of pure gold, or a maximum 40 months of imprisonment.

Based on the above description, it can be seen that Aceh applies different punishment to deal with drinking liquor in the second attempt. The difference is not only on the amount of the whipping, but also on its status. The status of whipping in the first attempt is hadd punishment, while the status of whipping in the second attempt is $t a^{\prime} z i r$ punishment ('uqubat ta'zir). Different from Brunei, the Qanun Jinayat of Aceh does not set the punishment for drinking khamr in the third attempt or the following. The difference is also found in determining the form of fine. Aceh applies pure gold, while Brunei Darussalam uses money as the form of fine.

The implementation of Islamic criminal law in Brunei Darussalam has almost fully complied with the order of the Islamic criminal law as thought in the Islamic criminal jurisprudence. This especially relates to the classification of offence and punishment into hudud, qisas and ta'zir. In Brunei, offence is classified into two major categories, namely: the hudud offence (jarimah hudud) that includes Qisas; and ta'zir offense (jarimah $\left.t a^{\prime} z i r\right)$. On the other side, the implementation of the Islamic criminal law in Aceh must be within the framework of the Indonesian legal system. ${ }^{32}$

As stated earlier, the differences in the application of Islamic criminal law in Aceh and Brunei Darussalam is not about hadd punishment ('uqubat hudud), rather on the determination of $t a^{\prime} z i r$ punishment ('uqubat ta'zir). The form of $t a^{\prime} z i r$ punishment was determined based on the discretion of the authority of each jurisdiction. Hence, the difference does not really matter, and it even shows the flexibility of the Islamic law.

\section{Conclusion}

Drinking khamr (liquor) is prohibited in Islam. This prohibition applies to all Muslims regardless their nationality and citizenship. Under the Islamic criminal jurisprudence, this offence is classified as jarimah hudud (hudud offences). The principal punishment for drinking khamr is whipping. The Prophet PBUH did not specify the amount of the whipping, but He had ever imposed 40 lashes for such an offence. The companions set forth the whipping for drinking khamr 40 lashes or 80 lashes. Based on this practice, the majority of scholar (jumhur 'ulama) set forth 40 lashes for the offence. Punishment other than this is considered as ta'zir punishment.

Drinking khamr has been defined as an offence both in Aceh and Brunei Darussalam. Regulation on khamr is available in a criminal legislation commonly referred to as Qanun Jinayat. Qanun Jinayat of Aceh and Qanun Jinayat of Brunei set forth similar

32 Aziz, S. (2014). “Kanunisasi Fikih Jinayat Kontemporer Studi Materi Muatan Qānūn Jināyat Aceh dan Brunei Darussalam”. Jurnal Pemikiran Hukum Islam (Al-Ahkam), Volume 24, Number 2, October 2014, p. 195. 
punishment for drinking khamr in the first attempt. According to Qanun Jinayat in both jurisdictions, drinking khamr in the first attempt is subjected to hadd punishment in the form of whipping not exceeding 40 lashes. Enforcement is carried out through the Shariah court (mahkamah syar'iyah).

The differences are found in several issues, including the form of $t a^{\prime} z i r$ punishment, the amount of fine, the proceedings and the applicability of each qanun. While Qanun Jinayat of Aceh is only applicable within its provincial territory, Qanun Jinayat of Brunei is applicable within its national territory. In addition, based on Islamic personality principle, the applicability of Qanun Jinayat of Brunei Darussalam is expanded to all Brunei Muslim citizens living abroad. 


\section{References}

Books:

Al-Khalafi and Abdul 'Azim bin Badawi. (2011). al-Wajiz: Ensiklopedia Fiqih

Islam dalam al-Qur'ān dan as-Sunnah as-Shahihiah. Jakarta: Pustaka asSunnah.

Ali, A. (2012) Menguak Teori Hukum dan Teori Peradilan. Jakarta, Brenada Media Group.

Al-Hilali. (1999). Salim bin Ied, Ensiklopedi Larangan menurut Al-Qur-an dan asSunnah, Jld.3, (Jakarta: Pustaka Imam Asy-Syafi' i, 1999)

Ash-Shabuni, M.A. (2001). Shafwatut Tafasir, Jilid. I. Jakarta: Pustaka al-Kausar. . (2001). Shafwatut Tafasir. Jilid. II. Jakarta: Pustaka al-Kausar.

Juned, A. A. A. (2013). Mufti Kerajaan Negara Brunei Darussalam, Qanun Jenayah Syar'iah Suatu Pengenalan, Brunei: Jabatan Mufti Kerajaan, Jabatan Menteri Negara Brunei Darussalam.

Kamus al-Munir. (2000). Surabaya: Khasiko.

Mumtaz Ali Tajddin, "Khamr in Encyclopedia Topic", accessed from

Mubarak, F. A. A. (2007). Ringkasan Nailul Authar, Jilid. 4. Jakarta: Pustaka Azzam.

Qanun Aceh Nomor 6 Tahun 2014 tentang Hukum Jinayat.

Qanun Aceh Nomor 7 Tahun 2013 tentang Hukum Acara Jinayat.

Rasyid, Sulaiman. (1978). Figh Islam, Jakarta; Athahiriyyah.

Sapardjaja, Komariah Emong, Makalah, Qanun Aceh, Jakarta, 07 March 2012.

Warta Kerajaan Negara Brunei Darussalam, Bahagian II, October 2013.

\section{Journal Articles:}

Arbas, C. (2018). “Aksiologis Mahkamah Konstitusi dalam Mewujudkan Demokrasi di Aceh", Jurnal Konstitusi, Volume 15, No. 1, Maret.

Aziz, S. (2014). "Kanunisasi Fikih Jinayat Kontemporer Studi Materi Muatan Qānūn Jināyat Aceh dan Brunei Darussalam". Jurnal Pemikiran Hukum Islam (Al-Ahkam), Volume 24, Number 2, October.

Ammar, K. (2016). “The Quran's Prohibition of Khamr (Intoxicants): A Historical and Legal Analysis for the Shake of Contemporary Islamic Economic", Kyoto Bulletin of Islamic Area Studies, 9 (March) p.97-112, https://www.asafas.kyotou.ac.jp/kias/pdf/kb9/04ea_02_ammar.pdf. Accessed on 10 May 2019

World Wide Web:

https://infokito.wordpress.com/2008/01/17/khamar/ accessed on 24 November 2013).

http://nicomunication.blogspot.com/2010/05/hukum-khamar-dalam-islam.html Accessed on 20 May 2019.

Pemerintah Provinsi Aceh http://id.wikipedia.org/wiki/Pemerintahan_Aceh, accessed on 24 August 2016.

Tajddin, M.A. "Khamr in Encyclopedia Topic", http://www.ismaili.net/heritage/node/10539, accessed on 11 May 2019 